\title{
Comparative Analysis of Crop Yields of Selected Crops (Maize, Rice and Kales) Before and After the Introduction of Irrigation Technologies in Kimira-Oluch Irrigation Schemes, Homa Bay County, Kenya
}

\begin{abstract}
Kenyan's economy is heavily dependent on agriculture which contributes greatly to gross domestic products (GDP). Nearly $80 \%$ of the country's population resides in the rural areas and are engaged directly in agricultural activities which account for over $75 \%$ of the total agricultural output. In addition, the sector contributes to food security, employment opportunities and income generation as well as nutritional balance to the farming families. It is therefore enough to say, agriculture still remains the backbone of the country's economy because of what it offers. Kenya has a huge potential of water resources including rivers, lakes and dams for the development of irrigation systems however, the country still continues to import food especially maize despite having ability to feed its own citizens. To solve the paradox of food insecurity, irrigation technologies need to in place. This paper therefore tries to compares the yields before and after the introduction of irrigation technologies in Kenya, precisely in Kimira-Oluch irrigation scheme using a paired t-test to determine whether there is statistically significant difference between productions level per unit area of selected crops (Maize, Rice and Kales) for participants of rainfed (before irrigation) and irrigated agriculture participants. From the results it was observed that, calculated value (observed) of $t$ was found to be -0.5150 which was in the acceptance region and thus, we accept $H_{0}$ and conclude that the difference in yields before irrigation (rainfed agriculture) and after irrigation (irrigated agriculture) is insignificance hence we can infer that irrigation technologies is not applied effectively in Kimira-Oluch thus resulting to a low yields. This is a clear indication that most of the factors of production such as irrigation waters and land are underutilized. The study will assist the policy makers and irrigation stakeholder to shift focus on innovations or technologies that can benefit both irrigation participants and non-irrigation participant.
\end{abstract}

Keywords: Crop Yields; Irrigation Technologies; Rainfed Agriculture; Irrigated Agriculture.

Copyright (C) 2020 The Author(s): This is an open-access article distributed under the terms of the Creative Commons Attribution 4.0 International License (CC BY-NC 4.0) which permits unrestricted use, distribution, and reproduction in any medium for non-commercial use provided the original author and source are credited.

\section{INTRODUCTION}

The existence of erratic rainfall in the study area had created uncertainty for crop production and emphasized the need for irrigation technology. Agriculture plays a critical role for economic growth and development for any developing countries [1] and its evident that, increase in $1 \%$ of agricultural crop productivity translates to a $0.6-1.2$ percent decline in the percentage of absolute poor farmers [2]. In subSaharan Africa for instance, agricultural production accounts for 35 percent of the gross domestic product (GDP) and employs over 70 percent of the rural population [1], and over 95 percent of the arable lands practice rainfed agriculture [3]. Therefore agriculture still remains the engine of overall economic development and growth thus considered the main poverty reduction tool all over the world $[4,5]$.

In many countries of the world rainfed agriculture has been a sole contributor of the world's highest yields and most of these regions are predominantly temperate climate with relatively reliable rainfall and inherently productive soils. Even in tropical regions countries, especially in the humid and subhumid zones, crop yields in commercial rainfed agriculture is more than 5-6 t/ha [6]. The rainfed agriculture varies region to region but yields most food for rural people in developing countries. In Africa, over 95 percent of arable lands are rainfed, while the corresponding figure for South Asia about 60 percent, for East Asia 65 percent for Latin America is almost 90 
percent whereas East and North Africa is 75\% [3]. All over the world, majority of the countries solely rely on rainfed agriculture for their food production. Despite enormous effort towards enhancing agricultural sector and environmental conditions in many developing countries, a huge number of poor farming families in Sub Saharan Africa and Asia still experiences food insecurity, hunger, malnutrition and poverty where rainfed agriculture is mostly practiced. This has even worsened the problems by adverse poor socio-economic infrastructure and also biophysical growing conditions in many regions in the arid and semi-arid areas (ASAL). The arid and semi-arid regions is the home to about 38 percent of the developing countries' poor and about 75 percent of whom stay in rural areas. It's evident that, more than 45 percent of the world's hungry and over 70 percent of its malnourished children comes from ASAL areas [7].

Kenya enjoys a diversity of climatic conditions and variety of soils however, less than 20 percent is regarded arable under rain-fed agriculture production while the remaining 80 percent is categorized as ASALs experiences water shortage a hindrance to agricultural production. For instance, in Homa Bay according to Republic of Kenya 2018 indicate that only $13.3 \%$ of the land with irrigation systems is being utilized to irrigate total of $(8,996)$ hectares, despite the County's huge potential to irrigate more land as it borders Lake Victoria which is the largest freshwater lake in Africa and the second in the world. According to Farm management handbook 2000, the annual rainfall of the County range from 700 to $800 \mathrm{~mm}$. Out of the land used for crop farming, about 104,467 hectares are set aside for food crop farming; 6,000 hectares for horticulture production while 12,227 hectares for cash crops [9]. Major horticultural crop grown under irrigation system in Kimira-Oluch includes onions tomatoes, kales, watermelon and capsicum. Other crops practiced in the area are maize, rice, beans, sorghum and sweet potatoes. However our main focus was on Maize, Rice and Kales since it form the main food stable in most farming families.

The existing farming systems or practices before the introduction of irrigation systems was characterized by mixed farming in small holdings farms of an average of 1.3ha and low farming input. Despite the low utilization of the available inputs, land is intensively utilized with little fallow land and some smallholder farmers trying double cropping in the short and long rains. Maize, beans, groundnuts and sorghum are the major crops; however, majority of the households have set aside small seasonal vegetable gardens as well. Almost all farmers cultivate staple crops. Low yields and crop failure were frequent due to irregular and unreliable rainfall patterns. The cropping system was based on the productivity of horticultural crops and annual crops [9]. The low food supply in the study area triggered initiation of the irrigation systems which the study intended to find out by comparing yields of the selected crops (Maize, Rice and Kales) before and after the introduction of irrigation technologies in Kimira-Oluch irrigation schemes, Homa Bay County, Kenya.

\section{Methods and Materials Study Area}

This research was carried out in Kimira scheme in Rachuonyo sub-county and Oluch scheme in Homa Bay sub-county, Kenya situated between latitudes and longitudes of $34^{\circ} 30^{\prime} \mathrm{E}$ and $34^{\circ} 39^{\prime} \mathrm{E}$ and $0^{\circ} 20^{\prime} \mathrm{S}$ and $0^{\circ} 30^{\prime} \mathrm{S}$ respectively along the shore side of Lake Victoria's Winam Gulf.

In terms of Agro-ecological Zones (AEZ), the county is categorized into seven AEZ. However, the focus was on Homa Bay sub-county (Oluch scheme) and Rachuonyo sub-county (Kimira scheme). Oluch scheme in Homa Bay sub-county for instance consist of two AEZ namely: Lower Midland (LM2), also known as marginal sugar zone where they grow green millet, grams, tobacco, sorghum, sunflower, beans, sugarcane, groundnuts, pineapples and sisal and Lower midland (LM3), also called cotton zone which grow crops such as sorghum, maize, cow peas, beans, ground nuts, soya, sweet potatoes, simsim, sunflower, green grams, vegetables and rice. On the other hand, Kimira scheme in Rachuonyo sub-county consist of Lower Midland (LM4), also called marginal cotton zone where they grow cotton, rice, beans, ground nuts, soya, sweet potatoes, simsim, sunflower, green grams and vegetables.

\section{Target Population and Sample Size Determination}

The study targeted individual smallholder farmers who crop identified crops, the extension officers and crop marketing groups. The estimated targeted households was 1,616 in Karachuonyo (Kimira) and 1,308 in Homa Bay town (Oluch) respectively with about 40 percent of the households being headed by women, based on "clan elders" which was crucial for researcher for easy mobilization of the resources and easy conflict resolution [8]. The targeted individual crop farmers was subjected for face to face interviews using a semi structured schedules and also the extension service providers from the two sub counties was purposely selected. Both qualitative and quantitative data was used to analyze the data.

Simple random and purposive sampling methods were employed. Simple random sampling was used to select irrigation participant and non-irrigation participants. The irrigation participants were selected based on irrigation water utilization. Here the researcher was guided into specific farmers by following the secondary drainage from the main primary canal whereas the non-participants were selected using the same method however, here the researcher targeted farmers without irrigation channel in their plots despite 
having access to water. Purposive sampling was used to select agricultural extension officers, since the agricultural extension officers were known, they were purposively chosen on the basis of who meets the purpose of the study at its best. The study therefore applied fisher formula [10] to give a representative sample size of 340 respondents which was distributed based on the area size Table 1.

Table-1: Sample Size Distribution in Kimira-Oluch Irrigation Scheme

\begin{tabular}{|l|c|c|c|c|c|}
\hline Sub-Counties & $\begin{array}{c}\text { Total } \\
\text { Area (ha) }\end{array}$ & $\begin{array}{c}\text { Total area Under } \\
\text { Irrigation (ha) }\end{array}$ & $\begin{array}{c}\text { Household } \\
\text { Beneficiaries }\end{array}$ & $\begin{array}{c}\text { No. of } \\
\text { Divisions }\end{array}$ & $\begin{array}{c}\text { Desired sample size } \\
\left(\frac{\boldsymbol{x}}{\boldsymbol{N}} \boldsymbol{X} \boldsymbol{n}_{\boldsymbol{f}}\right)\end{array}$ \\
\hline $\begin{array}{l}\text { Rachuonyo (Kimira } \\
\text { scheme) }\end{array}$ & 1,790 & 808 & 1,616 & $4(\mathrm{x})$ & 227 \\
\hline $\begin{array}{l}\text { Homa Bay town } \\
\text { (Oluch scheme) }\end{array}$ & 1,308 & 666 & 1,334 & $2(\mathrm{x})$ & 113 \\
\hline Totals & $\mathbf{3 , 0 9 8}$ & $\mathbf{1 4 7 4}$ & $\mathbf{2 , 9 5 0}$ & $\mathbf{6}(\mathbf{N})$ & $\mathbf{3 4 0}$ \\
\hline
\end{tabular}

Source; KNBS: (Where $\boldsymbol{n}_{\boldsymbol{f}}=\mathbf{3 4 0}$ )

\section{RESUlTS AND DisCUSSIONS}

Yield Levels per Unit Area of Selected Crops before and After the Introduction of Irrigation Technologies

The study sought to determine the production difference for Rainfed agriculture (before the introduction of irrigation technologies) and after the introduction of the irrigation technologies (irrigated agriculture). The findings revealed that, there was an increase in crop productivity due to the changes in water application. Whether this increase in productivity was significance or not, it was determined by testing the hypothesis. For instance, the acreage for Maize increase by $17.64 \%$ with yields increasing by $38.41 \%$, rice acreage increased by $40.57 \%$ with yields increasing by
$11.24 \%$, whereas kales acreage increased by $170.3 \%$ with an increase in production by $17.57 \%$ as shown in Table 2.

The average production difference further indicated a positive deviation in terms of yields for all crops under investigation for both rainfed and irrigated agriculture as shown in Table 2 under average production difference column. That is for maize the deviation was found to be +8.3 , for Rice it was +0.67 while for kales it was +1.94 . The increase in production was as result of shifting from rainfed agriculture to irrigated agriculture. However, we cannot say that whether the production was significance or not till their production means is subjected for hypothesis testing.

Table-2: Crop Production for Rainfed (Before) and Irrigated (After) for Maize, Rice and Kales

\begin{tabular}{|c|c|c|c|c|c|c|c|}
\hline \multirow{2}{*}{$\begin{array}{l}\text { TYPE } \\
\text { CROPS } \\
\text { GROWN }\end{array}$} & \multicolumn{2}{|c|}{ Av. Acreage Grown } & \multirow[b]{2}{*}{$\begin{array}{l}\text { Percentage } \\
\text { Increase }\end{array}$} & \multicolumn{2}{|c|}{$\begin{array}{c}\text { Average Production in } \\
90 \mathrm{Kg} \text { bag }\end{array}$} & \multirow[b]{2}{*}{$\begin{array}{l}\text { Percentage } \\
\text { Increase }\end{array}$} & \multirow{2}{*}{$\begin{array}{l}\text { Average } \\
\text { Production } \\
\text { Difference }\end{array}$} \\
\hline & $\begin{array}{l}\text { Rainfed } \\
\text { (Before) }\end{array}$ & $\begin{array}{l}\text { Irrigated } \\
\text { (After) }\end{array}$ & & $\begin{array}{l}\text { Rainfed } \\
\text { (Before) }\end{array}$ & $\begin{array}{c}\text { Irrigated } \\
\text { (After) }\end{array}$ & & \\
\hline \multirow{3}{*}{$\begin{array}{l}\text { Maize } \\
\text { Rice } \\
\text { Kales } \\
\end{array}$} & 5.95 & 7.00 & 17.64 & 21.61 & 29.91 & 38.41 & +8.3 \\
\hline & 5.25 & 7.38 & 40.57 & 5.96 & 6.63 & 11.24 & +0.67 \\
\hline & 7.44 & 20.11 & 170.30 & 11.04 & 12.98 & 17.57 & +1.94 \\
\hline $\begin{array}{l}\text { Average for } \\
\text { Selected crops }\end{array}$ & 6.21 & 11.50 & 76.17 & 12.87 & 16.51 & 22.41 & 3.64 \\
\hline
\end{tabular}

\section{Hypothesis Testing Using Paired t-test}

By using paired t-test to determine the mean difference between of production of selected crops (maize, rice and kales) before irrigation (rainfed agriculture) and after irrigation, irrigated agriculture. By letting production before (Rainfed Agriculture) be $\mathrm{X}_{1}$ and production after (irrigated Agriculture) be $\mathrm{Y} 1$ and then taking the null hypothesis that the mean difference between the two productions is zero i.e.

$H_{0}: \mu_{1}=\mu_{2}$ which is equivalent to test $H_{0}: D=0$

$H_{a}: \mu_{1}<\mu_{2}$ (as we want to conclude that irrigated agriculture always increases crop productivity.
Since we are having marched pairs, a paired t-test was used to work out test statistic as shown in equation 1 :

$$
t=\frac{\overline{\mathbf{D}}-\mathrm{O}}{\bar{\sigma}_{\text {diff } \sqrt{\mathrm{n}}}} \ldots \ldots \ldots . . \text { Equation }
$$

$$
\begin{array}{ll}
\text { Where: } & \\
\bar{D} & =\text { Mean of difference } \\
\sigma_{\text {diff }} & =\text { Standard deviation of difference } \\
\mathrm{n} & =\text { Number of matched pairs }
\end{array}
$$

To determine the value of $t$, first is to find out the mean and standard deviation of differences as shown in Table 3. 
Table-3: Testing of Hypothesis on Crop Production before and After Introduction of Irrigation Technologies

\begin{tabular}{|l|c|c|c|c|}
\hline Selected crops & $\begin{array}{c}\text { Rainfed Agriculture } \\
\text { Yields } \\
\left(\mathbf{X}_{\mathbf{1}}\right)\end{array}$ & $\begin{array}{c}\text { Irrigated Agriculture } \\
\text { Yields } \\
\left(\mathbf{Y}_{\mathbf{1}}\right)\end{array}$ & Difference & Difference squared \\
\hline Maize & 21.61 & 29.91 & $\mathbf{D}_{\mathbf{1}}=\left(\mathbf{X}_{\mathbf{1}}-\mathbf{Y 1}\right)$ & $\mathbf{D}_{\mathbf{1}}{ }^{\mathbf{2}}$ \\
\hline Rice & 5.96 & 6.63 & -8.3 & 68.89 \\
\hline Kales & 11.04 & 12.98 & -0.67 & 0.4489 \\
\hline $\mathrm{n}=3$ & & & $\Sigma \mathbf{D}_{\mathbf{1}}=-10.91$ & 3.7636 \\
\hline
\end{tabular}

To calculate the mean difference $(\bar{D})$, the following formulae was used $\bar{D}=\frac{\sum D_{1}}{n} \ldots \ldots \ldots \ldots . .$. Equition -2

Therefore the mean difference was found to be $\bar{D}=\frac{\sum D_{1}}{n}=\frac{-10.91}{3}=-3.64$

$$
\begin{aligned}
& \sigma_{\text {diff }}=\sqrt{\frac{\Sigma D_{1}{ }^{2}-\left(\bar{D}_{1}\right)^{2} * n}{n-1}}=\sqrt{\frac{73.10-(-3.64)^{2} * 3}{3-1}} \\
& =\sqrt{\frac{73.10-39.75}{2}} \\
& =\sqrt{\frac{33.35}{2}} \\
& =\sqrt{16.675}=4.08
\end{aligned}
$$

Therefore

$$
\sigma_{\text {diff }}=4.08
$$

To find $t$, by substituting the value into the equation 1 for calculation of $\mathrm{t}$

$$
t=\frac{\bar{D}-0}{\sigma_{\text {diff } \sqrt{\mathrm{n}}}}
$$

Hence the value of $\mathrm{t}$ is $=\frac{-3.64-0}{4.08 / \sqrt{3}}=\frac{-3.64}{7.067}$

$$
\mathrm{t}=-0.515
$$

Degrees of freedom $=n-1=3-1=2$.

Since alternative $(\mathrm{Ha})$ is one-sided, a onetailed test shall apply (in the left tail because $\mathrm{Ha}$ is of less than type) for determining the rejection side at $5 \%$ level of significance which comes to as by, using the table of $t$-distribution for 2 degrees of freedom then:

$$
R: t<-2.920
$$

Since the observed value of $t$ is -0.5150 which is in the acceptance region and thus, we accept $H_{0}$ and conclude that the difference in yields before irrigation (rainfed agriculture) and after irrigation (irrigated agriculture) is insignificance hence we can infer that irrigation technologies is not applied effectively in Kimira-Oluch thus resulting to a low yields. This is also a clear indication that most of the factors of production such as irrigation waters and land are underutilized.

The findings of this study are inconsistence with that of Makombe et al. [11] who found out that, in irrigated agriculture, farmers' productivity is more per unity area as compared to that of rainfed agriculture. However, on average, land under rainfed not utilized is relatively larger as compared to land under irrigation system. Makombe et al. [11], further explain that, when comparing the marginal and average productivities of inputs for the two scenarios, it shows that the mean productivity of the irrigated agricultural lands is relatively more in than that of rainfed production by cited a number of inputs such as fertilizers and pesticides that could have made yield to increase for the irrigated agriculture than rainfed where those inputs applied scarcely. In Kimira-Oluch the scenario was different, the available resources at their disposal were not fully utilized to realize a full potential of irrigation technologies.

\section{CONCLUSION}

Based on the study, it was concluded that crop productivity in rainfed agriculture is likely to be negatively impacted more on account of rainfall shortage, wet-day frequency and high temperatures as opposed to that in irrigated agriculture where rainfall and temperature are well managed thus improved productivity. The analysis of the productivity trends of Kimira-Oluch scheme for the selected crops under 
investigation such as maize, rice and kales, had a yield difference squared of $68.89, \quad 0.4489$ and 3.763 respectively. This clearly demonstrate that there is wide yield improvement between productivity in irrigated and rainfed agriculture except in the case of rice which require a lot of water for production, a case not applicable in both scenario. From the qualitative data, most farmers indicated that, rice is not much practices by many farmers in the study area due to intense management involved. However, the same phenomenons of productivity trends in irrigated and rainfed agriculture in all the selected crops evidently demonstrated that weather variability have major impact on yields. According to Kumar et al., [12, 13], the analysis carried out for the crops of bajra, sorghum and maize revealed that increased number of rainy days and rainfall would result in increased yield and viceversa. Higher temperatures were found to a major factor that influences the yields negatively in most crops.

\section{RECOMMENDATIONS}

These results revealed that, the irrigation technologies have profound impacts on farmers' livelihoods as well as household income. Therefore there is a need to engage farmers and encourage them to realize the full potential of irrigation in crop production. It has emerged that, the success of irrigation technologies deeply rely on the existence of an efficient and effective marketing channels or systems, therefore, for any irrigation farming to have significant impact on livelihood, poverty reduction and income generation, then linking smallholder farmers with markets and marketing channels would be the most immediate action needed.

\section{Suggestions for Further Research}

It was observed that, acreage for kale production increased by $170.29 \%$ as result of introduction of irrigation systems or technologies however, the production increased by only $17.57 \%$ which is insignificant. A further research is therefore needed to determine the cause of minimal yields and also to check whether post harvesting handling particularly of kales was done as required.

\section{ACKNOWLEDGEMENT}

I would like to acknowledge Prof. Basweti, Prof Maobe and Dr. Bunyatta for guidance and constructive criticisms in coming up with this paper which is an extract from my $\mathrm{PhD}$ thesis. Secondly, is to express my deepest gratitude to financial supporter of the African Development Bank (ADB) for the study from which this research paper was drawn.

\section{REFERENCES}

1. World Bank. (2000). Decentralising Agricultural Extension: Lesson and Good practice. [http://siteresources.worldbank.org/INTARD/8258 261111063678817/20431788/Decentalization.pdf] site visited on 12/11/2020.

2. Thirtle, C., Beyers, L., Lin, L., Mckenzie-Hill, V., Irz, X., Wiggins, S., \& Piesse, J. (2002). The impacts of changes in agricultural productivity on the incidence of poverty in developing countries. DFID report, 7946.

3. Faostat, F., \& Fisheries, D. (2005). Food and Agriculture Organization of the United Nations, Rome.

4. DFID. (2001). Sustainable livelihoods guidance sheets. Department for International Development (DFID), European Commission (EC), United. Retrieved from http://www.livelihoods.org/info/info_guidanceshee ts.html.

5. Konings, P. (1986). The state and rural class formation in Ghana: A comparative analysis Keegan Paul, London

6. Rockström, J., Steffen, W., Noone, K., Persson, Å., Chapin, F. S., Lambin, E. F., ... \& Nykvist, B. (2009). A safe operating space for humanity. nature, 461(7263), 472-475.

7. Wani, S. P., Rockstrom, J., \& Oweis, T. (eds). (2009). Rainfed agriculture: Unlocking the potential. Cambridge,London $\mathrm{CAB}$ international.

8. KOSFIP Appraisal Report. (2006). Kenyaappraisal-report-Kimira-Oluch-smallholder-farmimprovement-project.pdf/

http://www.afdb.org/fileadmin/uploads/afdb/docum ents/project-and-

9. Gok, M. S., \& Sezen, B. (2013). Analyzing the ambiguous relationship between efficiency, quality and patient satisfaction in healthcare services: the case of public hospitals in Turkey. Health policy, 111(3), 290-300.

10. Mugenda, Olive, M., \& Mugenda, Abel, G. (2003). Research Methods: Quantitative and Qualitative Approaches, Acts Press, Nairobi-Kenya

11. Makombe, G., \& Kelemework, D., \& Aredo, D. (2007) A comparative analysis of rainfed and irrigated agricultural production in Ethiopia. Irrig Drainage Syst, 21:35-44

12. Kumar, S. Raju B.K., Rama, C.A., Kareemulla, K., \& Venkateswarlu, B. (2011). Sensitivity of Yields of Major RainfedCrops to Climate in India, Ind. $J n$. of Agri.Econ; 66(3).

13. IFAD. (2012b). Gender and water. "Securing water for improved rural livelihoods: The multiple- uses system approach." IFAD, Rome. 